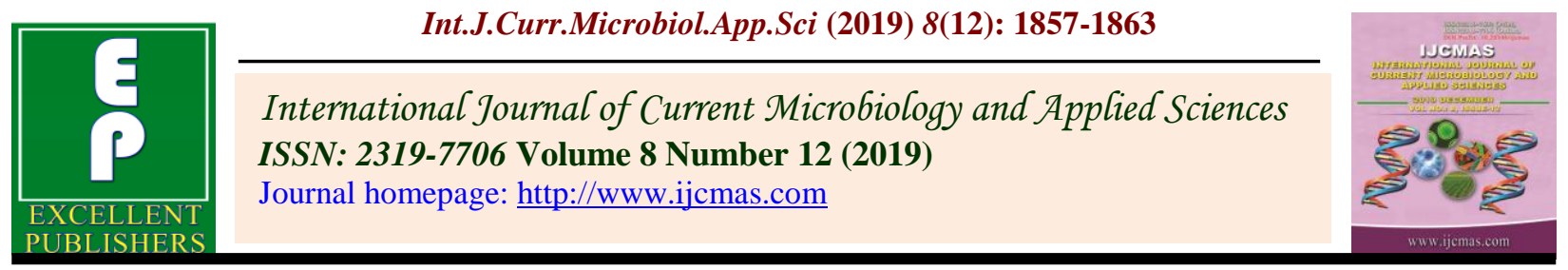

Original Research Article

https://doi.org/10.20546/ijcmas.2019.812.221

\title{
Correlation and Path Analysis Studies of Grain Yield Components in Rice Bean [Vigna umbellata] Genotypes
}

\author{
Sachin Kanthu Dharwad*, Mruthunjaya C. Wali, O. Sridevi and H. Basavarajeshwari
}

Department of Genetics and Plant Breeding, College of Agriculture, Dharwad, India University of Agricultural Sciences, Dharwad-580005, Karnataka, India

*Corresponding author

Keywords

Correlation, Grain yield, Path analysis, Ricebean, Seed yield

Article Info

Accepted:

15 November 2019

Available Online:

10 December 2019

\section{A B S T R A C T}

One hundred fifty genotypes of rice bean were evaluated for 12 different yield and yield related traits in augmented design at botany garden, Department of Genetics and Plant Breeding, Dharwad. The prime objective of current study was to evaluate the extent of association between pairs of characters at phenotypic levels and to know the direct and indirect effect of these characters. The study revealed that seed yield had positive and significant correlation with traits viz., days to maturity, plant height, number of branches, number of clusters, number of pods per cluster, pod length, number of seeds per pod, yield per plant and 100-seed weight. This indicates that selection based on these traits would be more effective. The path analysis studies revealed that days to maturity, number of clusters per plant and plant height had positive direct effect on grain yield

\section{Introduction}

Rice bean is self-pollinated crop with chromosome number of $2 \mathrm{n}=22$ (Kumar et al., 1945). It is one of the under-exploited legumes which have the potential to get commercial status in future due to its desirable agronomical and nutritional characteristics. The rice bean thrives well in the hot humid climate and is well distributed in the subtropical hilly regions. It grows well in soils ranging from sandy loam to heavy soils. It can withstand drought condition and it is photothermo-sensitive in terms of flowering and reproduction. Rice bean has high nutritional value and is composed of carbohydrate ranging from 58.2-72.0 per cent, crude protein ranging from 18.3-32.2 per cent and crude fibre ranging from 3.6-5.5 per cent of seed weight (Buergelt et al., 2009). Tryptophan and methionine are rich in rice bean (Carvalho and Vieria, 1996). The seeds are also affluent in other amino acids including valine, tyrosine and lysine. It is used as an animal feed, cover 
crop, green manure etc. This crop is resistant to most of the biotic and abiotic stresses. Rice bean is resistant to common pests and diseases associated with major pulse crops, of which the most severe disease is mung bean yellow mosaic virus (MYMV). It additionally has high levels of resistance to Cercospora leaf spot. Rice bean has resistance to insect pests such as pulse beetle and bean fly.

Yield is complex character which is influenced by many dependent and independent factors making it difficult to directly select for this character. Yield potential can be increased by choosing desirable combination of traits. To bring about desirable changes in yielding potential of rice bean it is essential to know the nature and extent of association existing among the different traits. Correlation is one such handy tool which helps in the selection of characters associated with the yield improvement.

Correlation measure the level of dependence traits and out of numerous correlation coefficients. A positive genetic correlation between two desirable traits makes the job of the plant breeder easy for improving both traits simultaneously. The estimates of correlations alone may be often misleading due to mutual cancellation of component traits. So, it becomes necessary to study path coefficient analysis, which takes in to account the casual relationship in addition to degree of relationship. The path coefficient analysis initially suggested by Wright (1921) and described by Dewey and Lu (1959) allows partitioning of correlation coefficient into direct and indirect contributions (effects) of various traits towards dependent variable and thus helps in assessing the cause-effect relationship as well as effective selection. Hence, this study was aimed to analyse and determine the traits having greater interrelationship with grain yield utilizing the correlation and path analysis.

\section{Materials and Methods}

The experimental material was comprised of 150 diverse rice bean genotypes involving indigenous and exotic lines and five checks were used. The experiment was conducted at botany garden Department of Genetics and Plant Breeding, Dharwad. The experiment was laid out in an augmented design with six blocks.

The plot size was single row of three meter length with a spacing of $45 \mathrm{~cm}$ between rows and $10 \mathrm{~cm}$ between plants. All other crop cultural management practices were followed to raise successful crop. The observations were recorded on five randomly selected plants for characters viz., days to $50 \%$ flowering, days to maturity, plant height $(\mathrm{cm})$, number of branches per plant, number of clusters per plant, number of pods per cluster, length of pod, number of seeds per pod, seed yield per plant $(\mathrm{g}), 100$ seed weight $(\mathrm{g})$, seed yield per plot $(\mathrm{g})$. The mean values were used for statistical analysis. Phenotypic correlation coefficients were worked out to find out the relationship between grain yield and their contributing characters. Path coefficient analysis was carried out using the simple correlation coefficient to know the direct and indirect effects of yield components on yield as suggested by Wright (1921) and illustrated by Dewey and Lu (1959).

\section{Results and Discussion}

The correlation coefficient between grain yield and its component traits were estimated at phenotypic levels. The phenotypic correlation coefficient of fourteen quantitative characters is presented in Table 1. Correlation is a beneficial approach which offers information involving how selection for a character results in improvement of positively correlated traits. It is of high significance when high heritable characters related with characters like yield. Correlation is deceptive 
if it is resultant of the indirect effect of different unrelated traits. Both genotypic and phenotypic correlation is of magnificent significance in crop improvement.

The genotypic correlation coefficient provides information on the affiliation of characters while phenotypic correlation coefficient is beneficial in finding out the selection index. Correlation, in the end, helps in the identification of most and least vital characters.

The correlation coefficient between dependent and independent variable is divided into its component parts: the direct effect or path coefficient (a standardized partial regression coefficient) for the independent variable and indirect effects which involve the production of a correlation coefficient between two independent variables with the appropriate path coefficient in the path diagram. By knowing the interrelationship among yield and yield contributing traits a better idea of indirect and direct effects can be obtained.

In the current study, all the characters are significant and positively correlated with seed yield per plot except for days to 50 per cent flowering which was negatively correlated but not significantly. Similar results were reported by Bharadwaj and Thakur (2017) and Kohakade et al., (2017) where in seed yield had significant positive correlation with days to maturity, plant height, pods per plant, pod length, seeds per pod, 100-seed weight, clusters per plant and pods per cluster stipulated that selection based on these traits would be effective. However contradictory results were reported by Thaware et al., (2000) and Sonone et al., (1999) wherein the days to fifty per cent flowering was found to be positively correlated with yield.

Days to 50 per cent flowering was found to be non-significant and negatively correlated with seed yield per plot (-0.0694) and other characters viz., plant height $(-0.0580)$, number of branches per plant ($0.0625)$, number of clusters per plant $(-0.0269)$, number of pods per cluster (-0.098), length of pod (-0.0811), number of seeds per pod (-0.0689), seed yield per plant $(-0.0563)$ and 100-seed weight (-0.0162). It showed a positive correlation with days to maturity (0.081) at the phenotypic level. Studies done by Arya et al., (2017) also found that the days to fifty per cent flowering was negatively correlated with plant height, number of branches, number of clusters per plant and number of seeds per pod.

At phenotypic level significant positive correlation was observed for grain yield per hectare with all other traits except days to 50 per cent flowering (-0.0694). Highest positive and significant correlation was observed between days to maturity and seed yield per plot with the $r$ value of 0.9766 . Other traits viz., plant height (0.9644), number of branches per plant (0.9249), number of clusters per plant (0.9676), number of pods per cluster (0.8279), length of pod (0.9372), number of seeds per pod $(0.9165)$, seed yield per plant (0.9359) and 100-seed yield (0.8938) were positively and significantly correlated with grain yield. Strong positive correlation of grain yield with most of the component characters indicated that selection for these traits can increase the grain yield.

Direct and indirect effects of different traits on grain yield are presented in Table 2 . In the current study, the highest magnitude of the direct positive effect was exhibited by days to maturity followed by clusters per plant, plant height and seed yield per plant, this indicated the presence of perfect relation between them hence selection based on these parameters would help in the selection of high yielding genotypes in rice bean. 
Table.1 Phenotypic correlation coefficients for yield and yield components in 150 genotypes of ricebean

\begin{tabular}{|c|c|c|c|c|c|c|c|c|c|c|c|}
\hline Traits & $\begin{array}{c}\text { Days to } \\
50 \% \\
\text { flowering }\end{array}$ & $\begin{array}{l}\text { Days to } \\
\text { maturity }\end{array}$ & $\begin{array}{l}\text { Plant } \\
\text { height } \\
\text { (cm) }\end{array}$ & $\begin{array}{c}\text { No. of } \\
\text { branches } \\
\text { per } \\
\text { plant }\end{array}$ & $\begin{array}{c}\text { No. of } \\
\text { clusters } \\
\text { per } \\
\text { plant }\end{array}$ & $\begin{array}{l}\text { No. of } \\
\text { pods } \\
\text { per } \\
\text { cluster }\end{array}$ & $\begin{array}{l}\text { Length } \\
\text { of pod } \\
(\mathrm{cm})\end{array}$ & $\begin{array}{c}\text { No. of } \\
\text { seeds } \\
\text { per } \\
\text { pod }\end{array}$ & $\begin{array}{c}\text { Seed } \\
\text { yield } \\
\text { per } \\
\text { plant } \\
\text { (g) }\end{array}$ & $\begin{array}{c}100 \\
\text { seed } \\
\text { weight } \\
(g)\end{array}$ & $\begin{array}{c}\text { Seed } \\
\text { yield per } \\
\text { plot }(\mathrm{g})\end{array}$ \\
\hline $\begin{array}{c}\text { Days to } 50 \% \\
\text { flowering }\end{array}$ & 1 & -0.0810 & -0.0580 & -0.0625 & -0.0419 & -0.0980 & -0.0811 & -0.0689 & -0.0563 & -0.0162 & -0.0694 \\
\hline $\begin{array}{l}\text { Days to } \\
\text { maturity }\end{array}$ & & 1 & $0.9669 * *$ & $0.9221 * *$ & $0.9547 * *$ & $\begin{array}{l}0.8418 \\
* *\end{array}$ & $\begin{array}{c}0.9265 \\
* *\end{array}$ & $\begin{array}{l}0.9174 \\
* *\end{array}$ & $\begin{array}{c}0.9364 \\
* *\end{array}$ & $\begin{array}{c}0.8928 \\
* *\end{array}$ & $\begin{array}{l}0.9766 * \\
*\end{array}$ \\
\hline $\begin{array}{c}\text { Plant height } \\
\text { (cm) }\end{array}$ & & & 1 & $0.9338 * *$ & $0.9618 * *$ & $\begin{array}{c}0.8231 \\
* *\end{array}$ & $\begin{array}{c}0.9036 \\
* *\end{array}$ & $\begin{array}{l}0.9120 \\
* *\end{array}$ & $\begin{array}{c}0.9016 \\
* *\end{array}$ & $\begin{array}{l}0.8970 \\
* *\end{array}$ & $0.9644 * *$ \\
\hline $\begin{array}{c}\text { No. of } \\
\text { branches per } \\
\text { plant }\end{array}$ & & & & 1 & $0.9441 * *$ & $\begin{array}{l}0.7878 \\
* *\end{array}$ & $\begin{array}{c}0.8738 \\
* *\end{array}$ & $\begin{array}{l}0.8792 \\
* *\end{array}$ & $\begin{array}{c}0.8906 \\
* *\end{array}$ & $\begin{array}{c}0.8965 \\
* *\end{array}$ & $0.9249 * *$ \\
\hline $\begin{array}{c}\text { No. of } \\
\text { clusters per } \\
\text { plant }\end{array}$ & & & & & 1 & $\begin{array}{l}0.8055 \\
* *\end{array}$ & $\begin{array}{c}0.9176 \\
* *\end{array}$ & $\begin{array}{l}0.9124 \\
* *\end{array}$ & $\begin{array}{l}0.9055 \\
* *\end{array}$ & $\begin{array}{c}0.9187 \\
* *\end{array}$ & $0.9676 * *$ \\
\hline $\begin{array}{l}\text { No. of pods } \\
\text { per cluster }\end{array}$ & & & & & & 1 & $\begin{array}{c}0.7981 \\
* *\end{array}$ & $\begin{array}{c}0.7833 \\
* *\end{array}$ & $\begin{array}{l}0.7974 \\
* *\end{array}$ & $\begin{array}{c}0.7592 \\
* *\end{array}$ & $0.8279 * *$ \\
\hline $\begin{array}{l}\text { Length of } \\
\operatorname{pod}(\mathrm{cm})\end{array}$ & & & & & & & 1 & $\begin{array}{c}0.8993 \\
* *\end{array}$ & $\begin{array}{l}0.9091 \\
* *\end{array}$ & $\begin{array}{c}0.8447 \\
* *\end{array}$ & $0.9372 * *$ \\
\hline $\begin{array}{l}\text { No. of seeds } \\
\text { per pod }\end{array}$ & & & & & & & & 1 & $\begin{array}{c}0.8608 \\
* *\end{array}$ & $\begin{array}{c}0.8533 \\
* *\end{array}$ & $0.9165 * *$ \\
\hline $\begin{array}{c}\text { Seed yield } \\
\text { per plant }(\mathrm{g})\end{array}$ & & & & & & & & & 1 & $\begin{array}{c}0.8628 \\
* *\end{array}$ & $0.9359 * *$ \\
\hline $\begin{array}{c}100 \text { seed } \\
\text { weight }(g)\end{array}$ & & & & & & & & & & 1 & $0.8983 * *$ \\
\hline $\begin{array}{l}\text { Seed yield } \\
\text { per plot }(\mathrm{g})\end{array}$ & & & & & & & & & & & 1 \\
\hline
\end{tabular}


Table.2 Path analysis of yield components on seed yield per plot in ricebean genotypes

\begin{tabular}{|c|c|c|c|c|c|c|c|c|c|c|c|}
\hline Characters & $\begin{array}{c}\text { Days to } \\
50 \% \\
\text { flowering }\end{array}$ & $\begin{array}{l}\text { Days to } \\
\text { maturity }\end{array}$ & $\begin{array}{c}\text { Plant } \\
\text { height } \\
\text { (cm) }\end{array}$ & $\begin{array}{c}\text { No. of } \\
\text { branches } \\
\text { per plant }\end{array}$ & $\begin{array}{c}\text { No. of } \\
\text { clusters } \\
\text { per plant }\end{array}$ & $\begin{array}{l}\text { No. of } \\
\text { pods per } \\
\text { cluster }\end{array}$ & $\begin{array}{l}\text { Length } \\
\text { of pod } \\
(\mathrm{cm})\end{array}$ & $\begin{array}{c}\text { No. of } \\
\text { seeds per } \\
\text { pod }\end{array}$ & $\begin{array}{c}\text { Seed } \\
\text { yield per } \\
\text { plant (g) }\end{array}$ & \begin{tabular}{|c|}
100 seed \\
weight $(\mathrm{g})$
\end{tabular} & $\begin{array}{c}\text { Seed } \\
\text { yield per } \\
\text { plot }(\mathrm{g})\end{array}$ \\
\hline $\begin{array}{c}\text { Days to } 50 \% \\
\text { flowering }\end{array}$ & -0.0051 & -0.0284 & -0.0087 & 0.0030 & -0.0130 & -0.0003 & -0.0094 & -0.0006 & -0.0069 & 0.0001 & -0.0694 \\
\hline $\begin{array}{l}\text { Days to } \\
\text { maturity }\end{array}$ & 0.0004 & 0.3512 & 0.1455 & -0.0443 & 0.2965 & 0.0029 & 0.1075 & 0.0075 & 0.1144 & -0.0050 & $0.9766 * *$ \\
\hline $\begin{array}{l}\text { Plant height } \\
\text { (cm) }\end{array}$ & 0.0003 & 0.3396 & 0.1505 & -0.0449 & 0.2987 & 0.0029 & 0.1048 & 0.0075 & 0.1102 & -0.0050 & $0.9644 * *$ \\
\hline $\begin{array}{c}\text { No. of } \\
\text { branches per } \\
\text { plant }\end{array}$ & 0.0003 & 0.3238 & 0.1405 & -0.0481 & 0.2932 & 0.0027 & 0.1014 & 0.0072 & 0.1088 & -0.0050 & $0.9249 * *$ \\
\hline $\begin{array}{c}\text { No. of clusters } \\
\text { per plant }\end{array}$ & 0.0002 & 0.3353 & 0.1447 & -0.0454 & 0.3106 & 0.0028 & 0.1065 & 0.0075 & 0.1106 & -0.0052 & $0.9676^{* *}$ \\
\hline $\begin{array}{l}\text { No. of pods } \\
\text { per cluster }\end{array}$ & 0.0005 & 0.2956 & 0.1239 & -0.0379 & 0.2502 & 0.0035 & 0.0926 & 0.0064 & 0.0974 & -0.0043 & $0.8279 * *$ \\
\hline $\begin{array}{l}\text { Length of } \\
\text { pod }(\mathrm{cm})\end{array}$ & 0.0004 & 0.3254 & 0.1360 & -0.0420 & 0.2850 & 0.0028 & 0.1160 & 0.0074 & 0.1111 & -0.0048 & $0.9372 * *$ \\
\hline $\begin{array}{c}\text { No. of seeds } \\
\text { per pod }\end{array}$ & 0.0004 & 0.3222 & 0.1372 & -0.0423 & 0.2834 & 0.0027 & 0.1043 & 0.0082 & 0.1052 & -0.0048 & $0.9165 * *$ \\
\hline $\begin{array}{l}\text { Seed yield } \\
\text { per plant (g) }\end{array}$ & 0.0003 & 0.3289 & 0.1357 & -0.0428 & 0.2812 & 0.0028 & 0.1055 & 0.0071 & 0.1222 & -0.0049 & $0.9359 * *$ \\
\hline $\begin{array}{c}100 \text { seed } \\
\text { weight }(\mathrm{g})\end{array}$ & 0.0001 & 0.3135 & 0.1350 & -0.0431 & 0.2853 & 0.0026 & 0.0980 & 0.0070 & 0.1054 & -0.0056 & $0.8983 * *$ \\
\hline
\end{tabular}

Residual effect -0.165 
These results were similar to that of Bharadwaj and Thakur (2017) and they revealed that besides these traits pods per cluster also found to be showing a direct positive effect on seed yield. Days to maturity and number of clusters per plant had a high indirect effect which contributed to the positive and significant correlation with seed yield/plot. The phenotypic residual effects were 0.165 indicating the addition of some more important attributes which had high weightage during selection for yield improvement.

On contrary to seed yield which is more complex the other yield related traits are less complex, and because of this by using some other traits which are strongly correlated with seed yield and has high heritability, will result in selection of best lines more reliable (Bekavak et al., 2008). The present study clusters per plant showed high heritability coupled with strong correlation with seed yield makes this character as important yield indicator in rice bean.

Seed yield per plot had a significant association with all the characters except for days to fifty per cent flowering which showed a non-significant negative association. The characters viz., the days to maturity and number of clusters per plant height, seed yield per plant, and length of pod exhibited a direct effect on seed yield per plot in the desired direction and also showed a strong correlation with yield. This confirms true association existing among them hence, direct selection would bring about an increase in yield. Correlation and path analysis revealed that the number of clusters per plant was the most important yield indicator in rice bean.

\section{Acknowledgement}

All the authors are very thankful to the Department of Genetics and Plant Breeding,
College of Agriculture, UAS, Dharwad, Karnataka, India, for providing all the necessary facilities during the work.

\section{References}

Arya, P., Gaibriyal, M.L., and Sapna, S.L. 2017. Correlation and path analysis for yield and yield components in blackgram (Vigna mungo). International Journal of Advanced Biotechnological Research. 7(2):382386.

Bekavak, G., Purar, B., and Jockovic, D. 2008. Relationships between line per se and testcross performance for agronomic traits in two broad-based populations. Euphytica, 162: 363-369.

Bhardwaj, N., and Thakur, S. 2017, Genetic analysis of variation for yield and related traits in the ricebean germplasm (Vigna umbellata (Thumb.)Ohwi and Ohashi) of NW Himalayas. International Journal of Current Microbiology and Applied Sciences. 6(11): 125-131.

Buergelt, D., Oppen, M.V., and Yadavendra, J.P. 2009, Quality parameters in relation to consumer preferences in ricebean. Presentation at the international conference on grain legumes: quality improvement, value addition and trade, February 14-16, 2009, Kanpur, India, pp. 58.62.

Carvalho, N.M., and Vieria, R.D. 1996, Ricebean [Vigna umbellata (Thumb.) Ohwi and Ohashi]. In: E. Nkowolo and J. Smartt (Eds). Legumes and oilseeds in nutrition. Chapman and Hall.pp: 222-228.

Dewey, D.R., and Lu, K.H. 1959. A correlation and path analysis of creasted wheat grass seed production. Agronomy Journal. 51: 515-518.

Kohakade, S.N., Bhavsar, V.V., and Pawar, V.Y., 2017. Correlation and path 
analysis for different characteristics in germplasm of moth bean [Vigna aconitifolia(Jacq.) Marechal]. International. Journal of Current Microbiology and Applied Sciences. 6(11): 2181-2186.

Kumar, L.S. 1945. A comparative study of autotetraploid and diploid types in mung Phaseolus radiate (Linn) Proc. Indian Academic. Sciences. 218: 226268.

Sonone, A.H., Jadhav, S.J., Dahat, D.V., and Aher, R.P. 1999. Path analysis in ricebean (Vigna umbellata (Thumb) Ohwi and Ohashi). Legume Research. 22(3): 195-197.

Thaware, B.L., Birari, S.P., Dhonukshe, B.L. and Jamadagni, B.M. 2000. Correlation between yield and yield attributes under different environments in ricebean. Indian Journal of Agricultural Research. 34 (1): 47-50.

Wright, S., 1921. Correlation and causation. Journal of Agricultural Research. 20: 557-587.

\section{How to cite this article:}

Sachin Kanthu Dharwad, Mruthunjaya C. Wali, O. Sridevi and Basavarajeshwari, H. 2019. Correlation and Path Analysis Studies of Grain Yield Components in Rice Bean [Vigna umbellata] Genotypes. Int.J.Curr.Microbiol.App.Sci. 8(12): 1857-1863. doi: https://doi.org/10.20546/ijcmas.2019.812.221 